\title{
神戸薬科大学エクステンション事業の展開と薬学教育との連携
}

\author{
長 嶺 幸子
}

\section{Cooperation between Extension Project and Pharmacy Education in Kobe Pharmaceutical University}

\author{
Sachiko Nagamine \\ Kobe Pharmaceutical University; Motoyma-kita 4-19-1, Higashinada-ku, Kobe 658-8558, Japan.
}

(Received August 30, 2011)

\begin{abstract}
In Kobe Pharmaceutical University, postgraduate continuing professional development (CPD) has been held every year since 1975. Kobe Pharmaceutical University Extension Center was established in June 2007. Kobe Pharmaceutical Extension Center is accredited as a credentialing body (G07) by the Council on Pharmacist Credentials. The extension project of Kobe Pharmaceutical University works together with the alumni association to provide ongoing opportunities for increasing pharmacist competence and professionalism. The extension program is continuing to develop expanded links with pharmacy education.
\end{abstract}

Key words_— continuing professional development (CPD); extension program; pharmacy education

\section{1.はじめに}

神戸薬科大学では, 昭和 50 年から卒後研修講座 を開講してきているが，さらなる薬剤師の生涯研修 を支援するために，平成 19 年 6 月に神戸薬科大学 エクステンションセンターを設立した．神戸薬科大 学エクステンションセンターは公益社団法人薬剤師 認定制度認証機構から西日本の薬系大学では初めて 「薬剂師生涯研修認証機関」として認証（G07）さ れた。薬剤師生涯研修の機会を提供するとともに, その結果を適切に評価することによって，薬剤師の 資質向上に寄与することを目的に認可された。エク ステンション事業は，同空会と連携してあらゆる職 域の薬剤師に向けて豊富な生涯研修の場と情報を提 供し，薬剤師としての専門的資質の更なる向上を継 続的に支援している.

2. エクステンションセンターの組織

エクステンションセンターの組織は, 学長をセン ター長とし，エクステンション事業の運営と支援を するために事業委員会を設置している. エクステン

神戸薬科大学（† 658-8558 神戸市東灘区本山北町 419-1)

e-mail: nagamine@ kobepharma-u.ac.jp

本総説は, 日本薬学会第 131 年会シンポジウム S29 で 発表したものを中心に記述したものである.
ション事業委員会はセンターの事業を円滑に運営す るとともに，薬剤師の生涯研修の支援にも寄与して いる。事業委員会のメンバーは，本学教員から4 名, 同空会から推薦された者 3 名の計 7 名で構成さ れている.

事業委員会の下部委員会として生涯研修企画委員 会が設置されている，生涯研修企画委員会は，神戸 薬科大学同空会本部生涯研修企画委員会と互いに緊 密に協力することにより，研修プログラムを企画し ている.この委員会のメンバーは，本学教員 6 名と 同空会本部生涯研修企画委員会のメンバーから推薦 された委員 4 名の計 10 名で構成されている.

またエクステンション事業委員会による薬剤師生 涯研修支援事業が円滑かつ適切に実施され，所期の 目的を達成しているか否かを評価し，事業委員会に 適切な指導又は助言を与えることにより，事業の改 善・充実と発展を図るために，生涯研修認定制度評 価委員会を設置している。評価委員会のメンバーは 本学の教員 1 名, 薬剂師職能団体から推薦された学 識経験者 2 名と同空会から推薦された者 1 名の計 4 名で構成されている.

エクステンションセンターの組織は, 研修プログ ラムの企画，運営を同空会と連携して行う体制を組 んでいる (Fig. 1). 


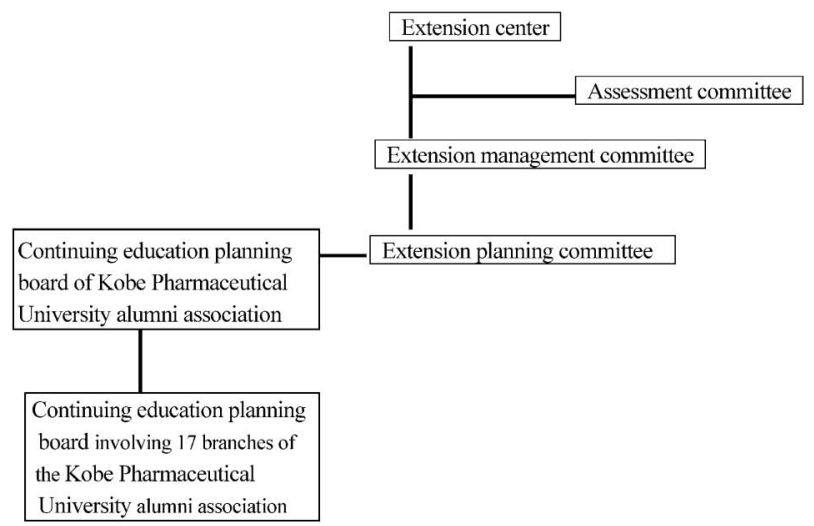

Fig. 1. Extension Center Organization Chart

\section{3. エクステンションセンター事業の展開}

医療の高度化そして急速な高齢化の進展と経済基 調の変化の中で薬学や薬剤師を取り巻く社会環境は 大きく変わってきている。このような社会におい て，医療の担い手としての薬剤師に大きな期待が寄 せられており，その期待に応えられる薬剤師の育成 が大学に求められている．大学は有能な薬剤師の育 成とともに社会で活躍する薬剤師への支援も求めら れており，本学では社会で活躍する薬剤師への生涯 研修の必要性を早くから認識し，その期待やニーズ に応えるために，「卒後研修講座」「リカレントセミ ナー」「薬剤師実践塾」「シンポジウム」「健康食品 講座」のコースを開講し，現場で活躍する薬剤師の 支援を行ってきた.

その他, 公開市民講座を平成 11 年から毎年開催 し，東灘区薬剂師会の協力で地域住民向けのお薬相 談コーナーや，その時々の話題を取り入れた講演な どを企画している。

\section{3-1. 卒後研修講座卒後研修講座は昭和 50} 年から毎年開講しており，平成 23 年で 37 回を数え ている.この講座は最新の医療や医学・薬学を学べ る場として現在学外でも広く認知され，その質の高 さは高く評価されている，卒後研修には，毎回 700 名を超える参加者があり，参加者の 20 数パーセン 卜は他大学出身者で占められている (Fig. 2).

3-2. リカレントセミナー＼cjkstart平成 10 年から卒 後研修講座のアドバンストコースとして，少人数で より専門的な内容を扱う「リカレントセミナー」を 年 2 回開講している。病院薬剤師, 薬局薬剤師など 職域別により専門的で高度な内容のテーマを取り上 げ，少人数のセミナー形式で実施している．専門疾

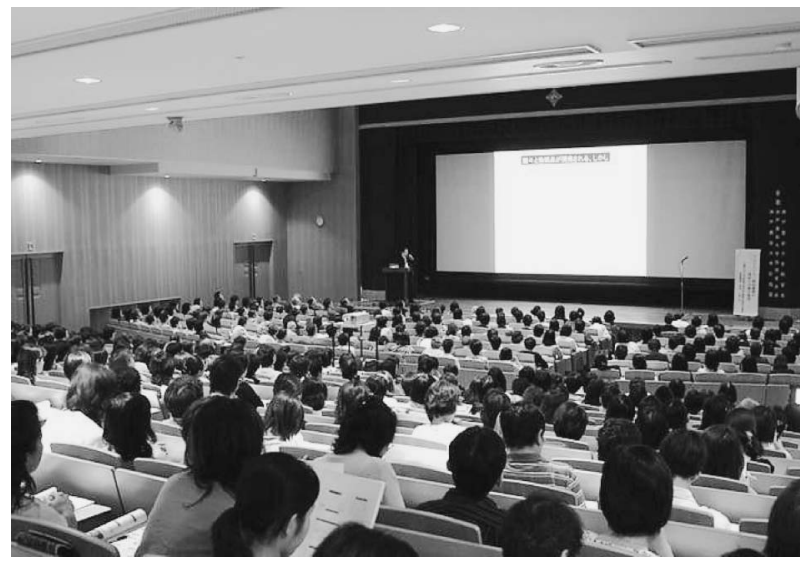

Fig. 2. Postgraduate Continuing Professional Development (CPD)

患領域別では病気に関する総論的な内容と実務に即 した内容を組み合わせてセミナーを企画しており， 臨床に即したテーマや系統だった内容で分かり易い と受講生からは非常に好評を博している．３年前か らは，症例検討シリーズが加わり，グループワーク を中心に実践的なセミナーも行っている. リカレン トセミナーも時代の要請を受け入れ，その時々に内 容を充実させてきた.

3-3. 薬剤師実践塾薬剤師を取り巻く環境 は，医療制度や法令の改革など，ますます厳しさを 増しており，このような状況の中で，活気のある職 場をつくり，その中でファーマシューティカルケア を積極的に実践しないことには, 薬剤師の存在価值 は極めて希薄になっていくことと思われる，患者中 心の医療を実践するには，それらを支える知識・技 能・態度等の資質の向上が基本となる。したがって 現在，業務の第一線で活躍している薬剤師の志気を 一層高め, チーム医療実践のためのリーダーシップ を身につけるためには，従来の講義形式の研修だけ では不十分であるということで，平成 16 年には， 「薬剂師実践塾」として実践的かつワークショップ 形式を取り入れたより少人数の参加型セミナーを開 講した.このプログラムは大きく 2 つに分かれ， 1 つは中堅薬剤師を対象としたリーダー研修，もう 1 つは離職後一定期間を経て, 再就職を考える薬剤師 のための再教育を目指すものである．この 2 つのプ ログラムでは，スモールグループディスカッション （SGD）を取り入れたり，模擬患者（SP）を対象に 実践的服薬指導を行ったりと実践的なプログラムを 
企画している，リーダー研修では，薬剤師の資質向 上を図るとともに，薬学 6 年制での学生実務実習に おける指導者として，教育者としての育成プログラ ムの立案にも積極的に取り組んできた.

平成 23 年度の実践塾では，再就職を考える薬剤 師のための再教育は一応所期の目的を果たしたとい うことで, 薬学部 4 年制卒の薬剂師のスキルアップ を目的とした研修を取り入れた。

3-4. シンポジウムシンポジウムでは，医療 の現場で，薬剤師に何が求められているのか，また 薬剂師は何をなすべきかなど社会のニーズを的確に 捉えて，それらの問題について様々な角度から意見 交換を行っている，そしてお互いに理解を深め，今 後の薬剤師のあり方をみんなで考えていくことを目 的としてシンポジウムを開催している．今までに 「ジェネリック医薬品の普及促進をめぐる薬剤師の 役割」，「薬剤師はバイタサインを薬物治療にどのよ うに活かすか」，「プライマリケアにおける薬剤師の 役割」を開催し，そして今年は「臨床思考能力を持 つた薬剤師の育成に向けて」についてシンポジウム を開催した。

3-5. 健康食品講座生活習慣病予防に係わる 特定健康診査・特定保健指導制度が始まり，国民の 健康への関心がますます高まってきている。、ルス ケアのために健康食品やサプリメントの利用が増え てきている，それに伴い健康食品やサプリメントの 安全面も含めたヘルスケアアドバイザーとしての役 割も薬剤師に求められてきている，以上のような事 情に鑑み，平成 20 年度から神戸薬科大学では「健 康食品指導薬剂師制度」を発足させ，健康食品に係
わる様々な知識を深めてもらおうと研修会を企画し ている。

4. エクステンションセンター事業と薬学教育の 連携

薬剂師実践塾のリーダー研修では, 薬学教育 6 年 制での学生実務実習の指導者として活動するための 研修を行い，また教育者としての育成プログラムも 実践的に行ってきた。 その成果を「ワークシートで 教える薬局実務実習指導ガイド」として 2010 年 7 月に発刊した。また卒後研修講座を大学院の特論科 目としても開講し，昼夜開講制大学院特論も聴講可 能にしている。これら研修プログラムを受講し研修 認定薬剤師となった病院薬剤師や薬局薬剤師は，実 務実習での学生指導や実務実習事前教育にも指導薬 剤師として参画することで，神戸薬科大学は継続的 な薬薬学連携を図っている。

またエクステンションセンターの様々な事業に参 加するよう学生にも㗢きかけている，学生と薬剤師 が一緒に学ぶことで, 学生には現場の薬剤師の方々 の積極的な姿勢や，コミュニケーションを通じて現 場の持つている知識の豊富さや経験を知ることで自 分たちの学ぶ方向性を知るよい機会となっていると 考えている．また現職の薬剤師にとっては，学生が 大学で何を学んでいるのか知るよい機会にもなると いう意見も聞かれた。

\section{5. まとめ}

神戸薬科大学エクステンションセンターでは，今 後も各種の研修プログラムを企画し，提供すること で，地域医療の一層の向上のために貢献する計画で ある。 